\title{
COMPARISON OF THE IMPACT OF THE ARAB SPRING AND TERRORIST ATTACKS ON THE DECLINE IN TOURISM IN EGYPT AND TUNISIA (2010-2015)
}

\author{
Jan A. WENDT* \\ Gdańsk University, Faculty of Oceanography and Geography, Institute of Geography, \\ Bażyńskiego str. 4, 80-952 Gdańsk, Poland, e-mail: jan.wendt@ug.edu.pl
}

\begin{abstract}
Citation: Wendt, J.A. (2019). COMPARISON OF THE IMPACT OF THE ARAB SPRING AND TERRORIST ATTACKS ON THE DECLINE IN TOURISM IN EGYPT AND TUNISIA (2010-2015). GeoJournal of Tourism and Geosites, 27(4), 1367-1376. https://doi.org/10.30892/gtg.27421-440
\end{abstract}

\begin{abstract}
Tourism industry plays an important role in many countries while in several dozen ones, including Egypt and Tunisia, it is perceived one of the most significant sectors of the countries' economy. The main objective of the paper is to analyse the changes in tourist air traffic in Egypt and Tunisia during a period of challenging political transition called the Arab Spring in Egypt and the Jasmine Revolution in Tunisia as well as the influence of the terrorist attacks on tourists which took place in the two above-mentioned countries in 2014, 2015 and in the first half of 2016. The author will make an attempt to assess the magnitude of the negative impact of the political riots and terrorist attacks on the decrease in tourist traffic measured by a decrease in the tourist air traffic and in the number of tourists visiting the analysed countries. Egypt and Tunisia have been selected for the analysis as their anthropogenic and natural attractiveness make them the main tourist destinations for Europeans.
\end{abstract}

Key words: the Arab Spring; terrorist attacks; policy; tourism business; tourist traffic, air transport

\section{INTRODUCTION}

Tourism is one of the fastest-growing sectors of services in the modern world. The number of tourists increased 50 times in the period of 1950-2015, from 25 million in 1950 to approximately 1180 million in 2015. During the first ten months of 2015 the number of tourists reached 1,015 billion and it surged by $4 \%$ in comparison to the corresponding period of the previous year. According to UNWTO international tourist arrivals are forecast to reach 1.8 billion by 2030. Tourism industry plays an important role in many countries while in several dozen ones, including Egypt and Tunisia, it is perceived one of the most significant sectors of the local (Herman et al., 2016; Gozner et al., 2017; Ilieș et al., 2016, 2017, 2018; Lincu et al., 2018) and countries' economy (Ilieş \& Wendt, 2015; Esmail, 2016). Not surprisingly, the phenomenon of tourism attracts

\footnotetext{
* Corresponding author
} 
attention of governments, local authorities, entrepreneurs and numerous scientists as this multifaceted phenomenon is one of the most profitable service sectors. Especially in the context of terrorist attacks, which already have very rich literature (Sönmez, 1998; Sönmez \& Graefe, 1998a; 1998b; Neumayer, 2004; Araña \& León, 2008; Llorca-Vivero, 2008; Baker, 2014; Albu, 2016; Liu \& Pratt, 2017). During the period of 1950-2015 income from tourism increased from 2 billion USD to 1,2 trillion USD (Tourism Highlights, 2015). The revolutions in Arab countries called the Arab Spring in Egypt and the Jasmine Revolution in Tunisia leading to political transformation have had a significant impact on safety of tourists visiting these countries. This insecurity has led to a visible drop in tourist air traffic in both Egypt and Tunisia.

The same effect was observed after the terrorist attacks. Egypt and Tunisia have been selected for the analysis of changes in tourist air traffic as their anthropogenic and natural attractiveness make them the main tourist destinations for people living in Europe. The term political factors refers to all important political events affecting internal policies and in the case of terrorist attacks - those affecting international policies. Bearing in mind the subject of this study, which is air traffic and the objective of the paper, which is determination of the magnitude of impact the political factors exert, the analysis does not contain detailed descriptions of the transformation processes taking place in each country - only the milestones are highlighted as they are affect tourist image of the country gathering media attention. In order to grasp the magnitude of changes in tourist air traffic the airports/cities perceived as the main tourist destinations in both countries have been selected. Their tourist nature is assessed on the basis of their demographic potential, tourist attractions and functions they perform.

\section{SUBJECT AND METHODS OF RESEARCH}

The subject of the analysis are changes in tourist air traffic in Egypt and Tunisia during a period of challenging political transition called the Arab Spring in Egypt and the Jasmine Revolution in Tunisia as well as the influence of the terrorist attacks on tourists which took place in the two above-mentioned countries in 2014, 2015 and in the first half of 2016 (Neagu, 2017). The objective of the study is an attempt to assess the magnitude of the negative impact of the political riots and terrorist attacks on the decrease in tourist traffic measured by a decrease in the tourist air traffic and in the number of tourists visiting the analysed countries. Answering two questions seems to be cognitively and scientifically interesting. The first one is: which of the events which took place in Egypt and Tunisia, the Arab Spring or the terrorist attacks, caused a larger drop in tourist traffic in the two mentioned countries? The second question regards durability of the downward trend in the tourist traffic observed in the analysed countries. The main problem concerning the analysis and correlation was access to reliable data on tourist traffic and for some airports it was difficult to obtain reliable data on passenger traffic. The main data source for the Egyptian airports were the Egyptian Holding Company for Airports and Air Navigation (EHCAAN) and the Ministry of Civil Aviation for the period of 2007-2015 and for Tunisia it was the „List of the busiest airports in Africa" and data derived from official websites of airports .

The most essential data which allows to assess the actual impact of the political events on tourist traffic in the analysed countries are the years of the Arab Revolution, which are 2011-2013. However, to grasp a wider background, the whole period of 20102015 are to be analysed. The same period will be taken under consideration in the context of the terrorist attacks of 2014 and 2015. The author will also attempt to evaluate the influence of the political events and terrorist attacks on the economy of 
both Egypt and Tunisia as their economies depend heavily on the tourist industry. The study involved simple, classic research methods. They are methods of statistical analysis of changes in tourist traffic and the analysis of the correlation between these changes and the political events and terrorist attacks in the analysed countries (Wendt \& Bógdal-Brzezińska, 2018). The statistical analysis was also used to estimate further changes in tourist traffic. Due to the progress of the Egyptian revolution, the period 2010-2014 has been chosen for the analysis of the influence of the political events on tourist traffic while in Tunisia, where the process of political stabilization had finished earlier, the period of 2010-2012 has been chosen.

Due to data accessibility, in order to assess the influence of the terrorist attacks in both countries, the year of 2015 and the first half of 2016 have been selected. Notwithstanding, while analysing the passenger traffic volume at the airports in Egypt and Tunisia, it has to be kept in mind that the changes in the number of passengers indicate only the overall changes in passengers traffic and they cannot be perceived as indicators of overall changes in tourist traffic (Ilieş \& Wendt, 2015). However, it seems to be eligible to conclude on the number of tourists on the basis of the changes in number of passengers at the airports as for European of Russian tourists planes are the main means of transportation when travelling to North Africa.

\section{TERRORIST ATTACKS IN EGYPT AND TUNISIA FROM 2014 TO 2016}

The political riots in Egypt and Tunisia were accompanied by terrorist acts on political opponents and the governmental forces from the very beginning (Aziz, 1995; Neagu, 2018). However, initially the main targets of the attacks in Egypt were not tourists. Although, as soon as in 2005 there was a terrorist attack in Sharm el-Sheikh and over 70 people died, including tourists from the United Kingdom, the Netherlands, France, Kuwait, the Czech Republic, Italy, Spain and Israel, over the next ten years tourist could feel relatively safe in Egyptian resorts. However, just after the short period of political stabilization and one year after Al-Sisi became the President, on 31st of October 2015 there was a terrorist attack on a Russian airliner A321 operated by Kogalymavia. According to the experts' opinion, a bomb brought down the Russian airliner over the Sinai desert. Two hundred and twenty-four Russians died and an Egyptian branch of the Islamic State claimed responsibility for the attack.

It was a form of retaliation for Russian engagement in the war in Syria. Russia made a decision to immediately evacuate its citizens from Egypt. Next year, the president announced introduction of the prohibition of organizing tourist trips to Egypt. Further terrorist attacks, like the explosion in an Egyptian city of Al-Arisz, where in November (24.11.2015) two car-bombs went off next to the entrance to Swiss Inn hotel. After this attack, several further tourist offices deleted their offer in Egypt. What is more, on 7th of January, two masked men opened fire on a tour bus waiting for tourists near one of the hotels located along the road to Giza. Fortunately, this time no one was hurt. The two perpetrators were caught by the police and they admitted being members of the Muslim Brotherhood and claimed that the attack was to intimidate the tourists. At the same time, in Bella Vista hotel in Hurghada other two attackers armed with knives hurt two tourists from Austria and one coming from Sweden. The ministers of many European countries issued communications in which they discouraged their citizens from visiting Egypt. Likewise, Tunisia also has a history of terrorist attacks.

In 2008, El Ghriba synagogue on the Tunisian island of Djerba was attacked. Twenty-one people died in the attack, including 14 German tourists. Al-Kaida claimed responsibility for this attack. As for the next several years there were no further attacks, 
Tunisia became one of the most popular tourist destination for Europeans. However, the Jasmine Revolution and the successful attempt to democratize the politics were not commonly accepted by the citizens of Tunisia. One of the firsts terrorist attacks in which several Tunisian soldiers died took place in the Tunisian mountains in July 2014. However, just like in Egypt, the first attacks were aimed at the representatives of the government, not the tourists. Nonetheless, as soon as on 18th March 2015, during a failed attempt to attack the Parliament in Tunis, two attackers withdrew to the building of the Bardo National Museum where they killed 24 tourists from France, Italy, Japan, Poland, Tunisia, Spain, Colombia, Belgium, Russia and the United Kingdom.

In this case, just like in Egypt, the Islamic State claimed responsibility for the attack. As a result, more and more people were cancelling their trips to Tunisia and Tunisian hotels were affected by the growing losses. On 26th June 2015, two masked attackers opened fire at tourists sunbathing on the hotel beach in Sousse - one of the most fashionable Tunisian resorts. Thirty-eight foreigners died, including thirty tourists from the United Kingdom, three from Ireland, two from Germany and one person from Belgium, Portugal and Russia. The attacker had been trained in Libya, and once again the Islamic State claimed the responsibility for the massacre. In effect, many tourist offices from the UK and Germany were cancelling trips to Tunisia.

\section{THE DECLINE IN THE NUMBER OF TOURISTS AT AIRPORTS IN EGYPR AND ITS CONSEQUENCES}

In order to analyse the changes in tourist passenger traffic at airports in Egypt it is necessary to divide the airports into two groups. The first group comprises airports where many different groups of passengers are serviced - they are: Cairo and Borg alArab in Alexandria. The second one comprises airports were mainly tourists are serviced. However, this group can be further divided into two subgroups. The first subgroup comprises the airports located in regional tourist centres, which are: Sharm el-Sheikh, Hurghada and Luxor. The second one congregates the airports in the remaining Egyptian tourist destinations: Marsa Alam, Aswan, Abu Simbel and Taba.

Table 1. Passenger traffic at the selected Egyptian airports (in thous) (Data source: basis of data derived from the Egyptian Holding Company for Airports and Air Navigation, 2015 Wendt, 2016)

\begin{tabular}{|l|c|c|c|c|c|}
\hline Air port & 2010 & 2011 & 2012 & 2013 & 2014 \\
\hline Cairo & 16148 & 13037 & 14729 & 13774 & 14685 \\
\hline Borg al-Arab & 712 & 1004 & 1975 & 2261 & 2507 \\
\hline Hurghada & 8063 & 5975 & 7136 & 5783 & 7226 \\
\hline Sharm el-Sheikh & 8694 & 5476 & 6625 & 5953 & 6239 \\
\hline Luxor & 1971 & 914 & 810 & 640 & 611 \\
\hline Marsa Alam & 1182 & 820 & 1089 & 914 & 1160 \\
\hline Aswan & 955 & 338 & 294 & 250 & 270 \\
\hline Taba & 446 & 309 & 282 & 189 & 45 \\
\hline Abu Simbel & 490 & 119 & 74 & 36 & 11 \\
\hline
\end{tabular}

Obviously, serving almost 15 million passengers, Cairo is being ranked first as it is the capital city and a large centre of tourist traffic. The second and third place, in both 2010 and 2014, were taken by typical tourist destinations which are Sharm el-Sheikh, a city situated on the southern tip of the Sinai Peninsula and Hurghada in the Red Sea.

In 2010, Luxor took the fourth place. It is a city located in the centre of Egypt with its temples and necropolises of the Pharaohs. However, in 2014 Borg al-Arab in 
Alexandria took its place as it served 2,5 million of passengers that year. However, not only the passenger traffic volume matters, but the analysis of its changes also.

In order to do so, it is important to provide at least some basic information on the political transformation which took place in Egypt in the period of 2011-2012 as they have been presented in the previous chapter of the paper. As it has already been stated, the key events like strikes, manifestations and others hampering tourist traffic took place in 2011 and 2013. In 2011, the beginning of the Arab Spring, strikes and street fights in Cairo calmed down after H. Mubarak had resigned.

A peace period started and tourists started again visiting Egyptian resorts relatively quickly. However, the problems with the elections, new constitution, decrees of the new president M. Mursi wanting to create a confessional state and, finally, the military coup all together resulted in a decrease in tourist traffic volume in 2013.

The influence of the above-mentioned political events on the passenger traffic in Cairo is clearly visible as in 2011 a fall of 3 million tourists was recorder in comparison to 2010 when 16 million tourists visited the city. In the next year, after the situation had been calmed, again the number of tourists increased and it reached 14,7 million in 2012. However, another year of strikes, manifestations and the military coup lead to a drop in the number of tourists - one million less passengers were served in Cairo in 2013 in comparison to 2012. The decrease is not as big as in 2011 as the military coup did not bring chaos. Despite overthrowing the legal government, the coup brought political stabilization. Although it was enforced by the army, still it was stabilization.

A new airport in Borg al-Arab did not record a decrease in the number of passengers, but is a result of deceleration in the growth rate. In 2010/2009 it was 91\% while in $2011 / 2010$ it was only $41 \%$ as a result of the riots. Then, in 2012/2011 it increased to $97 \%$ as it was a period of political stabilization. After that, in 2013/2012 and $2014 / 2013$ it dropped to $14 \%$ and $11 \%$ respectively (Table 1 ). A basic comparative analysis of tourist and demographic potential has shown that Hurghada, Sharm elSheikh and Luxor are the main centres of tourist traffic in their regions (Nowak \& Wendt, 2010). The passenger traffic at the airports in these destinations showed the same fluctuations as in Cairo. It is obvious, as it was affected by the same political events. However, this decrease was far higher than the decrease in Cairo, as it concerned mainly tourist traffic which is so sensitive to any changes in the level of safety. In Hurghada the number of passengers dropped by $26 \%$ in 2011/2010, in Sharm by $37 \%$ and in Luxor by $54 \%$. Although the next year brought an increased number of passengers, but not in Luxor. However, the next drop in 2013 clearly confirms the thesis that the internal political events and the foreign tourists traffic are highly correlated in Egypt. Although, the volume of passengers traffic at the two airports by the Red Sea Taba and Marsa Alam is definitely lower, as Hurghada and Sharm el-Sheikh had been claimed the best resorts for European tourists, there the correlation between political events and tourist traffic is also visible. In 2011 and 2013 a decline in the number of passengers reached $30 \%$ and $16 \%$ respectively while in Taba it was $30 \%$ and up to $33 \%$.

The last figure recorded in Taba in 2013 may also be explained by its proximity to the border with Israel and the policies towards Palestinians pursued by both Israel and Egypt. In 2014 the airport in Taba was virtually closed as it served only 45 thousand of passengers, which constitutes only 10\% of the number of passengers served in 2010. 2010 was the most profitable for the Egyptian tourist industry.

The airports in Aswan and Borg al-Arab do not only serve the tourist traffic as they are located in the northern and southern parts of the country, they mainly serve domestic passenger traffic. The airport in Abu Simbel is not as popular among tourists. 
The city is known for its temples which have been relocated with the assistance of some Polish archaeologists. Their relocation was necessary as they were under threat from the rising waters of the Nile that were about to result from the construction of the Aswan High Dam. The complex is located in the far south of Egypt and it takes 4,5 hours to reach them by bus departing from Aswan. It is a classic example of a city having world class monuments. Although the temples are part of the UNESCO World Heritage Site, they are the only attraction to see during a whole-day bus trip from Aswan and back. Here, the means of road transport are more popular than planes.

The analysis of the passenger traffic at Abu Simbel airport is even more interesting, as it also has confirmed the strong linkages between politics and tourism. During the period of 2009-2010, when the economic crisis in Europe and the US decreased the number of passengers from 650 thousand in 2005 to 450 thousand -490 thousand tourists chose to fly to Abu Simbel although it was much more expensive than taking a bus. The Arab Revolution resulted in another drop in the number of passengers. The number decreased by $76 \%$ and later the tourist traffic in Abu Simbel was only decreasing more. Finally, in 2014 it reached 10 thousand people. As a result of the Arab Spring in 2011 the number of tourists in Egypt decreased by 35\%, from 14,7 million to 9,5 million (Butterfield et al., 2012; Abdou \& Zaazou, 2013). Although the next year brought an increase to 11 million tourists, lack of political stabilization triggered another drop - by 2 million in 2013. One year later, in 2014, there was a slight increase in the number of tourists. In that year 9,6 million tourists visited Egypt and generated 7,5 million USD income (Al-Shuwekhi, 2015). After the terrorist attacks in 2015 and 2016 another significant drop in the number of tourists visiting Egypt was recorded. Although, in 2014 the number of tourists increased by 4,5\% in comparison to 2013, as the Egyptian statistical agency CAPMAS claims, during the next years a noticeable decrease in the tourist traffic took place. From January to April 2015 1,58 million tourists visited Egypt, while a year before there were 3,08 million visitors.

According to CAPMAS in 2015 9,3 million tourists arrived in Egypt, which is 5,6\% less than in 2014. The number of tourists 2015 decreased by $40 \%$ in comparison with the record reached in 2010 (15 million people). After the terrorist attacks which took place in the second half of 2015 and at the beginning of 2016, the number of tourists visiting Egypt in the first four months of 2016 decreased by $48,78 \%$ in comparison to the same period in 2015. The analysis of the tourists' structure has revealed lack of Russians who used to be a large group of people spending their holidays by the Nile. The Egyptian tourist industry was actually based on the Russians and it was significantly affected by the introduction of prohibition to fly to Egypt after the attack on the Russian plane returning with tourists from Sharm el-Sheikh in October 2015. In the structure of tourists who visited Egypt in the first quarter of 2016 there were only 13\% of people coming from Eastern Europe, half of them were Ukrainians. Almost one third of the visitors were form Western Europe $-36 \%$ of them were Germans. However, the percentage of tourists coming from the Middle East did not change and it was 30\%. The crisis in Egyptian resorts will be probably deepen by the catastrophe of the Egyptian airliner flying from Paris to Cairo having 224 people on board which disappeared over the Mediterranean Sea in May 2016.

Such a significant decrease in the tourist traffic has a great impact on the economy. The smaller the number of tourists, the less people selling papyrus, perfumes, souvenirs or mineral water earn. A slump in incomes of taxi drivers, tourist guides, people selling sweets and cigarettes on beaches was recorded. According to the press releases issued by CAPMAS, the number of tourists decreased by $46 \%$ in February 2016 (Ayyad, 2016), including a 99\% drop in the number of Russians visiting Egypt. 
Income from tourist activities in Egypt was 500 million dollars in the first quarter of 2016 - it was three times less compared with the same period in 2015.

\section{THE DECLINE IN THE NUMBER OF TOURISTS AT THE AIRPORTS IN TUNISIA AND ITS CONSEQUENCES}

Similarly to the Arab Spring in Egypt, the Jasmine Revolution in Tunisia was reflected in the number of passengers served at Tunisian airports. Data for the period of 2010-2015 shows clearly that the number of passengers and tourists at all airports, except for the new one in Enfidha, dropped significantly. Even the airport located in the capital city served $18 \%$ people less than in 2011 than in 2010.

The two classic tourist airports in Monastir and Djerba recorded $71 \%$ and $26 \%$ drops in the number of passengers respectively. Such a significant decrease in tourist traffic in Monastir not only can be explained by the political events, but also by the facts that some part of the tourist traffic was moved to Enfidha. In 2012, after the revolution had finished, the number of passengers increased again to the level of 2010.

However, at the airports in Monastir and Djerba the number of passengers did not reached the value which had been recorded two years earlier (Table 2).

Table 2. Passenger traffic at the selected Tunisian airports (in thous) Data source: Annuaire Statistique de la Tunisie, 2014

\begin{tabular}{|l|c|c|c|}
\hline \multicolumn{1}{|c|}{ Air port } & $\mathbf{2 0 1 0}$ & 2011 & 2012 \\
\hline Tunis - Carthage & 1961,7 & 1613,3 & 1988,2 \\
\hline Jerba - Zarzis & 1133,9 & 842,2 & 868,4 \\
\hline Monastir & 1729,8 & 498,6 & 611,5 \\
\hline Enfidha & 244,0 & 637,3 & 1032,9 \\
\hline
\end{tabular}

The Revolution of 2011 affected the economy of Tunisia significantly, especially the tourist sector (Becheur, 2011). In 2010 approximately 7 million of tourists visited Tunisia while in 2011 just 4,9 million - the volume of tourist traffic and income from tourism dropped by one third. According to the World Travel \& Tourism Council, in the period of 2013-2014 almost $15 \%$ of the Tunisian economy was linked with the tourist industry and this industry generated $7 \%$ of GDP (The Travel \& Tourism Competitiveness Report, 2015). During the first eight months of 2014 almost one million tourists visited Tunisia - less when compared with the same period of the previous year. What is more, the number of Europeans decreased by 50\%. In the whole 2014 the number of tourists dropped by 3,4\% when compared with 2013. It was 6,07 million tourists in 2014 which was 800 thousand less than in 2010 and 200 thousand less than in 2013. The already difficult situation of the Tunisian economy, approximately $10 \%$ of hotels were closed, got even worse after the terrorist attacks in 2015 .

Table 3. Changes in the number of Germanand British tourists visiting Tunisia in 2015/ 2014 (in \%) (Data source: www.anna.aero/2015/10/o7/tunisia-tourism-scares-are-resulting-in-declining-passenger-traffic/)

\begin{tabular}{|c|c|c|c|c|c|c|c|c|}
\hline State & January & February & March & April & May & June & July & August \\
\hline Germany & 8,4 & $-2,8$ & $-14,8$ & $-36,2$ & 0,0 & $-17,7$ & $-43,9$ & $-51,5$ \\
\hline United Kingdom & 7,5 & 19,2 & 13,4 & 10,3 & 8,7 & $-0,9$ & $-84,3$ & $-94,1$ \\
\hline
\end{tabular}

After the attacks in the Bardo National Museum in Tunis in March and on the beach in Sousse in June when many German and British tourists died, the passenger traffic at the airports in Enfidha and Monastir decreased by almost a half. The largest 
drop was recorded in August 2015 when the number of passengers decreased by more than $80 \%$. As the table above shows, the Bardo Museum attack (March 2015) led to a significant decrease in the number of German passengers and a visible drop in the number of tourists visiting Tunisia in the next months of 2015 in comparison to the same period of 2014. After the 18th of March 2015 lots of hotel reservations had been cancelled and in April the number of German tourists decreased by $36 \%$ when compared with 2014. The attacks which took place in June were catastrophic for the tourist sector of Tunisia. When compared to July 2014, in July 2015, the number of tourists from Germany decreased by $44 \%$ and by $85 \%$ from the United Kingdom, as many victims of the Sousse attack were British (Table 3).

\section{CONCLUSION}

In 2011 passenger traffic at the airport in Sharm El-Sheikh decreased by $37 \%$ and in Hurghada by $26 \%$ in comparison to 2010 (Table 1). The stabilization of political situation in 2012 resulted in an increased number of passengers, but not at all analysed airports.

A significant increase in the number of passengers served in Cairo (1,7 million), Borg al-Arab (0,97 million), Hurghada (1,16 million), Sharm (1,15 million) and Marsa Alam (270 thousand) was recorded while at the airports in Taba, Aswan, Abu Simbel and Luxor a decrease by 27000, 42000, 45000 and 104000 respectively were noted. The 2014 increase in the number of passengers, after the drop in 2013 which had been triggered by the political events, including the military coup, did not regard the airports in Luxor and Taba. In Abu Simbel the situation was even worse, as the number of passengers reached only 11 thousand in 2014 - only $1 / 45$ of the number of passengers served in 2010 - before the revolution. What is more, the situation is worsened by the unstable political situation and the terrorist attacks in Libya, Gaza, North Sudan and on the border with Israel.

It seemed that 2015 would have been the year when the Egyptian tourist industry will be reborn. Although it was gained by force, the strong military power, confirmed by the presidential elections won by Abd al-Fattah as-Sisi, which were officially recognized by the international community, was perceived as a chance for political stabilization and further development of tourism. However, the increase in the number of tourists in passenger air traffic was hampered in 2014 after the terrorist attack on the Russian airliner (Airbus A321) taking off from Sharm el-Sheikh Airport in October 2015 (31.10.2015). As a result of this attack in which 220 passengers died, Russia withdrew the recommendation for tourist trips to Egypt and the relevant authorities prohibited any tours to this destinations. Similar decisions on flights to Sharm were made by the United Kingdom and several other countries are considering to do so. The next terrorist attacks, the explosion in the city of Al-Arisz in North Sinai where two bombs hidden in a car went off near the entrance to Swiss Inn hotel in November 2015 (24.11.2015). It finally confirmed lack of stabilization and a low level of safety what will definitely result in a further decrease in the tourist traffic in the first half of 2016.

Table 4. The number of tourists visiting Tunisia and Egypt (in millions) Data source: own elaboration based on: data.worldbank.org/indicator

\begin{tabular}{|l|c|c|c|c|c|}
\hline Country & 2010 & 2011 & 2012 & 2013 & 2014 \\
\hline Egypt & 14,7 & 9,5 & 11,2 & 9,2 & 9,6 \\
\hline Tunisia & 6,9 & 4,9 & 5,9 & 6,3 & 6,1 \\
\hline
\end{tabular}

The data on the passenger traffic in Tunisia has shown a significant decrease in the number of tourists in the analysed period. At times of the revolution the number of passengers served by the airport in Tunis decreased by $18 \%$ and by $26 \%$ and $71 \%$ in 
Djerba and Monastir respectively. A decrease in the number of tourists was also recorded in 2012 (Table 2). According to the World Travel \& Tourism Council in 2014 the number of tourists visiting Tunisia dropped by $15 \%$, including a $50 \%$ decrease in the number of European tourists (The Travel \& Tourism Competitiveness Report, 2015).

When compared to 2010, the number of people arriving in Tunisia in 2011 decreased by 2 million (Table 4). Although in 2012 the volume of tourist traffic increased showing a tendency to stabilization in the period of 2013-2014, the number of tourists in 2014 was still lower by 800 thousand in comparison to 2010, which was a record-breaking year in Tunisia. After the terrorist attacks in the Bardo National Museum and on the beach in Sousse where lots of German and British tourists died, the passenger traffic at the airports in Enfidha and Monastir decreased by nearly half. The record-breaking decrease took place in August 2015 when the general number of passengers dropped by more than $80 \%$ (Table 3). As the presented data on changes in the number of passengers served at the selected airports and on the volume of the tourist traffic in Egypt and Tunisia shows, the dynamics of changes triggered by the political events and terrorist attacks is differentiated. Political events affect the number of tourists to a smaller extent and they have a long-lasting effect (Table 4). Most probably this situation can be explained by lower prices encouraging tourists, especially those from East Europe, to visit Egypt and by a high safety level in the resorts warranted by the military and police during the Arab Spring. In the case of Tunisia, just like in Egypt, the number of tourists dropped after the Jasmine Revolution.

However, in the next years, until 2014, a stable but small increase in the number of people visiting this country was observed. In turn, terrorist attacks result in an almost immediate, significant drop in the number of tourists, especially from the countries which citizens were victims of the attack (Table 3). However, it is worth mentioning that the number of tourists visiting countries where terrorist attacks took place increases at a relatively fast pace. Egypt is an exception, as Russian tourists have never come back as a result of the Russian government's decisions. The only bright side of this situation is the fact that the terrorist attacks in Egypt did not result in a constant decrease in tourist traffic which was decreasing, sometimes even by $1 / 3$, but in the next years, thanks to exceptional tourist attractiveness of Egypt, it was growing again.

\section{REFERENCES}

Abdou, D.S. \& Zaazou, Z. (2013) The Egyptian revolution and post-economic impact. Topics in Middle Eastern and African Economies, 15, 1, 92-115.

Albu, C.E. (2016). Tourism and terrorism: a worldwide perspective. CES Working Papers, 8, 1, 1-19.

Al-Shuwekhi, A. R. (2015). USD 7,5 bn tourism income to Egypt in 2014. Daily News Egypt (www. dailynewsegypt. com/2015/02/01).

Araña, J.E. \& León, C.J. (2008). The impact of terrorism on tourism demand. Annals of Tourism Research, 35, 2, 299-315.

Ayyad, M. (2016), Tourism inflow declines by $45.9 \%$ in February: CAPMAS (www.dailynewsegypt.com/2016/ 04/ 04/tourism-inflow-declines-by-45-9-in-february-capmas).

Aziz, H. (1995). Understanding terrorist attacks on Tourist in Egypt. Tourism Management, 16, 91-95.

Baker, D. \& Mc. A. (2014). The Effects of Terrorism on the Travel and Tourism Industry. International Journal of Religious Tourism and Pilgrimage, 2, 1, 58-67.

Becheur, M. (2011). The Jasmine Revolution and the Tourism Industry in Tunisia. UNLV Theses/Dissertations/ Professional Papers/Capstones. Paper 1141, Las Vegas, University of Nevada.

Butterfield, W.M., Atalla, S., Hakim, R. \& Yacoub, S. (2012). Assessment of the Tourism Sector in Egypt, USAID.

Esmail, H. (2016). Impact of Terrorism and instability on the tourism industry in Egypt and Tunisia after Revolution. The Business and Management Review, 7, 5, 469-475. 
Herman, G.V., Deac, A.L., Ciobotaru, A.M., Andronache, I.C., Loghin, V. \& Ilie, A.M. (2016). The role of tourism in local economy development. Bihor County case study. Urbanism. Arhitectură. Construcţii, 8, 3, 265-274.

Gozner, M., Tătar, C.F., Stupariu, M. \& Măduta, F.M. (2017). Nature, Photography and Tourism in BihorVlădeasa Mountains (Romania). GeoJournal of Tourism and Geosites, Year X, Volume 20, OradeaGdansk, Romania-Poland, Editura Universităţii din Oradea.

Ilieș, A., Hurley P.D., Ilieș, D.C. \& Baias S. (2017). Tourist animation -a chance adding value to traditional heritage: case studys in the Land of Maramures (Romania), Revista de Etnografie şi Folclor, New Series 1-2.

Ilieș, D.C., Oneț, A., Marcu, F.M., Gaceu, O.R., Timar, A., Baias, Ș., Ilieș, A., Herman, G.V., Costea, M., Țepelea, M., Josan, I. \& Wendt, J.A. (2018). Investigations Regarding The Air Quality in the Historic Wooden Church in Oradea City, Romania. Environmental Engineering and Management Journal, Vol.17, no11, pp.2731-2739 (http://www.eemj.icpm.tuiasi.ro/pdfs/accepted/204_294_Ilie\%C8\%99_17.pdf);

Ilieş, A. \& Wendt, J.A. (2015). Geografia turystyczna. Podstawy teorii i zagadnienia aplikacyjne. Wydawnictwo AWFiS, Gdańsk.

Ilieș, A., Wendt, J.A., Ilieș, D.C., Herman, G.V., Ilieş, M. \& Deac, A.L. (2016). The patrimony of wooden churches, built between 1531 and 2015, in the Land of Maramureș, Romania. Journal of Maps, Volume 12, 2016, pp 597-602 - Issue sup1 (http://dx.doi.org/10.1080/17445647.2016.1243075).

Lincu, A., Ilieș, M., Ilieș, D.C., Herman, G.V., Baias, S., Gozner, M., Costea, M., \& Mihincău, D. (2018). Conservating the traditional cellars of Salacea, Bihor County, Romania. GeoJournal of Tourism and Geosites, 23(3), 748-758, https://doi.org/10.30892/gtg.23311-325.

Liu, A. \& Pratt, S. (2017). Tourism's vulnerability and resilience to terrorism. Tourism Management (C), 60, 404-417.

Llorca-Vivero, R. (2008). Terrorism and international tourism: New evidence. Defense and Peace Economics, $19,2, \mathrm{~m} 169-188$.

Neagu, F.S. (2017). The impact of the terrorism on North African tourism. Proceedings of the International Conference on Business Excellence, 11, 1, 1081-1087.

Neagu, F.S. (2018). The influence of geopolitical events on tourism in Egypt. Proceedings of the International Conference on Business Excellence, 12, 1, 661-670.

Neumayer, E. (2004). The Impact of Violence on Tourism - Dynamic Cross-National Estimation. Journal of Conflict Resolution, 48, 2, 259-281.

Nowak, M. \& Wendt, J. (2010). Hurghada as one of the major destination of Polish tourism. In: Wendt J., (eds.), Chosen problems of geographical research in Poland and Romania, 99-109, Editura Universitatii din Oradea.

Sönmez, S. (1998). Tourism, terrorism, and political instability. Annals of Tourism Research, 25, 2 416-456.

Sönmez, A.F. \& Graefe, A.R. (1998a). Influence of terrorism risk on foreign tourism decision. Annals of Tourism Research, 25, 1, 112-144.

Sönmez, A.F. \& Graefe, S. (1998b). Determining future travel behavior from past travel experience and perception of risk and safety. Journal of Travel Research, 37, 2, 172-177.

Wendt, J.A. (2016). Zmiany w turystycznym transporcie lotniczym Egiptu w latach 2005-2014, Prace Komisji Geografii Przemysłu Polskiego Towarzystwa Geograficznego, 4(30), 92-101.

Wendt, J.A. \& Bógdał-Brzezińska, A. (2018). Problematyka, metody i problemy badań w geografii turystycznej. Olszewski-Strzyżowski D.J., Dróżdż R., Pasek M., (red.), Turystyka. Nowe Trendy, Zeszyty Naukowe, 7, Polska Izba Turystyki, 7-42.

Wendt, J.A. \& Wiskulski, T. (2016). Zmiany w światowym transporcie lotniczym w segmencie turystycznym w latach 2008-2015. Problemy Transportu i Logistyki, 3(35), 187-197.

*** Annuaire Statistique de la Tunisie (2014), www.ins.tn/fr/publication/annuaire-statistique-de-la-tunisie-2014.

**** Egyptian Holding Company for Airports and Air Navigation EHCAAN (2015). www.ehcaan.com/statistics. aspx.

**** List of the busiest airports in Africa (2015). www.list of the busiest airports in Africa.

**** The Travel \& Tourism Competitiveness Report 2015 (2015). World Economic Forum, Geneva.

**** Tourism Highlights (2015). UNTWO, 2015 Edition.

*** Tunisia tourism scares are resulting in declining passenger traffic (2015). www.anna. aero/2015/10/07/ tunisia-tourism-scares-are-resulting-in-declining-passenger-traffic.

Submitted:

22.09.2019
Revised:

17.12.2019
Accepted and published online 19.12.2019 